\title{
ENGLISH ARBITRATION PRACTICE
}

\author{
G. Ellenbogen* \\ I \\ INTRODUCTION
}

"Arbitration" is a term of wide compass. In addition to its primary meaning of adjudication, it is often used where "conciliation" would be more appropriate. This ambiguity is particularly marked in the field of employment and industrial relations; the Civil Service Arbitration Tribunal, for example, like the recently superseded National Arbitration Tribunal, is principally concerned with fixing rates of pay. Arbitration of this kind is entirely outside the scope of this article.

In its more restricted sense, arbitration in English law covers three types of extra-judicial adjudication. Arbitration proceedings may arise (1) from an arbitration agreement (or "submission") voluntarily entered into by the parties; (2) from an order of the court compelling the parties to settle their dispute by arbitration, e.g., a reference from a High Court judge to an Official Referee; and (3) from statutory provisions, such as are commonly found in enactments dealing with housing, town and country planning, land, building, rating, health and nationalization. Although much of what follows would apply to compulsory arbitration by order of court and to statutory arbitration under act of Parliament, this article purports to deal only with voluntary arbitration, and in particular with arbitration in the field of commerce.

\section{II}

\section{Legal Aspects of English Arbitration}

\section{A. Attitude of the Law to Arbitration}

In their discussion of the medieval guilds, Pollock and Maitland wrote:" "There can hardly exist a body of men permanently united by any common interest that will not make for itself a court of justice if it be left for a few years to its own devices." It was a similar common interest-though more fluctuating or transient in character-that gave rise to the local commercial courts of the middle ages, the courts

* M.A. (Cantab.); Bacon Scholar of Gray's Inn and Barstow Scholar of the Inns of Court; of Gray's Inn and the Northern Circuit, Barrister-at-Law. Lecturer on the Law of Sea and Air Transport at the City of London College. Author, The Principles of the Criminal Law Relating to Insanity, I J. Crum. Sc. (1948). Assistant Editor, Hood Phillips, Constirutionaz Law (7th ed. 1952). Joint Editor, CleRK \& LiNDSELL, LAw of TORTS (IIth ed.) (in preparation).

${ }^{1}$ No attempt is made in this article to give a systematic exposition, even in summary form, of the rules of English law relating to arbitration. Only certain points of special relevance to the relationship between commercial arbitration and law are discussed here. A systematic treatment of the English law of arbitration may be found in Russell on Arbitration (15th ed. 1952), in II Hazsnury's Laws op England (3d ed.) (in press), and in Clive M. Schmitthoff, Export Trade-A Manual of Law and PrActice, c. 24 (2d ed. 1950).

${ }^{2}$ I Pollock and Maitland, The History of English Law 667 (2d ed. 1898). 
of pie-powder giving summary judgment at markets and fairs, and the maritime courts of seaport towns, "sitting on the seashore from tide to tide."

Royal justice looked askance at these private jurisdictions; and so courts of the staple were set up to compete with the local mercantile courts, and courts of admiralty to supersede the local maritime courts. Yet these royal courts remained closer to the needs of merchants than the common law courts, with their highly technical and rigid rules of evidence and procedure. Thus in the first court of admiralty case of which we have record (I36I) the court overruled a demurrer with the words, "this court, which is the office of the admiral, will not be so strictly ruled as the other courts of the realm which are ruled by the common law of the land, but is ruled by equity and marine law, whereby every man will be received to tell his facts...."

In the course of centuries, the common law courts engulfed nearly all these special jurisdictions, but, in so doing, they incorporated into the common law many of those mercantile rules which had earlier to be proved in every case. Yet the law must always lag behind commercial practice. To take a well-known instance, bills of exchange were familiar to English merchants by the middle of the sixteenth century; but while litigation on bills was practicable enough in the Court of Admiralty, it was not until Holt became Chief Justice of the Kirg's Bench at the end of the seventeenth century that the negotiability of bills of exchange was recognized at common law; and Holt himself refused to acknowledge promissory notes as being on the same footing, maintaining that they represented an attempt by Lombard Street to dictate law to Westminster Hall. ${ }^{4}$

The inevitable discrepancy between law and commercial practice ${ }^{5}$ rendered it necessary, in spite of the constantly increasing ambit of the law, for merchants to compose their differences without resort to the courts. The growing practice of arbitration in an expanding economy could not be indefinitely ignored by the legislature: and so in 1698 a statute was passed, ${ }^{6}$ of which Blackstone wrote, "experience having shown the great use of these peaceable and domestic tribunals, especially in settling matters of account, and other mercantile transactions, which are difficult and almost impossible to be adjusted on a trial at law, the legislature has now established the use of them." The Act provided, inter alia, that it "shall and may be lawful for all merchants and traders and others desiring to end any controversy, suit or quarrel ... for which there is no other remedy but by personal action or suit in equity, by arbitration to agree that their submission of their suit to the award or umpirage of any person or persons should be made a rule of any of His Majesty's Courts of Record which the parties shall choose ..." and that "any arbitrage or umpirage pro-

${ }^{3}$ Cited in T. Plucknetr, A Concise History of the Common Law 623 (4th ed. 1948).

'See PluckNetr, op. cit. supra, at 631; Buller v. Cripps, 6 Mod. 29, 87 Eng. Rep. 793 (K.B. 1704).

"See [Mr. Justice] Patrick Devlin, The Relation Between Commercial Law and Commercial Practice, I4 Mod. L. REv. 249 (195x). For his comments on commercial arbitration in particular, see id. at $258-260$.

o 9 \& 10 WILL. 3 , c. 15.

73 Br. Coms. * 17. 
cured by corruption or undue means shall be judged and esteemed void and of none effect, and accordingly be set aside by any court of law or equity. ..."

The subsequent history of arbitration legislation may be summarized, very briefly, as follows. The Civil Procedure Act, $1833,{ }^{8}$ rendered the authority of an arbitrator irrevocable (except by leave of the court), made refusal to attend an arbitration as witness, in defiance of an arbitrator's order, a contempt of court, and empowered an arbitrator to administer the oath. The Common Law Procedure Act, I854, contained a considerable number of sections devoted to arbitration, and may be said to have formed the framework of the modern law. It was superseded, so far as its arbitration provisions were concerned, by the Arbitration Act, 1889. ${ }^{10}$ The date of this Act is significant; for it was at about this time that the practice grew up, in the Chamber of Shipping and other great mercantile associations, of issuing standard contract forms containing arbitration clauses, and, with the resulting increase in the number of commercial arbitrations, the need became apparent to improve the ancillary legal machinery and to devote a special statute to it.

Until recently, the Arbitration Act, 1889, remained "the principal Act." Apart from a minor amendment contained in Section 16 of the Administration of Justice Act, $1920,{ }^{11}$ it was amended by the Arbitration Clauses (Protocol) Act, $1924,{ }^{12}$ to give effect to a League of Nations Protocol under which it was agreed that no action should be brought on any contract between nationals of the contracting states which contained an arbitration clause; and it was further amended by the Arbitration (Foreign Awards) Act, $1930,{ }^{13}$ to enable the award in any such arbitration to be enforced in the United Kingdom. Then the Arbitration Act, 1934, ${ }^{14}$ following the recommendations of a Committee set up under Mr. Justice MacKinnon to report on requisite changes in the law relating to arbitration, ${ }^{15}$ amended the principal Act in some important respects. Recently, the whole of the arbitration legislation was consolidated in the Arbitration Act, $1950^{16}$

The jealousy and suspicion with which the law was once apt to regard arbitration have been succeeded by an attitude of tolerance and benevolence. The legislature has intervened to implement arbitration agreements and to enable the force of judgments to be given to arbitration awards, and the judges have evinced a readiness to construe generously the powers given to arbitrators by statute, ${ }^{17}$ and to overlook irregularities where no miscarriage of justice is involved. Indeed, the judges have frequently expressed their reluctance to be invoked at all by a party to an arbitration agreement. As Scrutton, L. J., said in Re Olympia Oil \& Cake Co., and MacAndrew, Moreland \& Co.: ${ }^{18}$

${ }^{8} 3 \& 4$ WILI. 4 , c. 42.

11 IO \& II GEO. 5, c. 81.

1424 \& 25 Geo. 5, c. 14.

I7 \& I8 Vicr. c. I25.

${ }^{12}$ I4 \& 15 GEO. 5, c. 39.

${ }^{15} \mathrm{CMDD}$. No. $28 \mathrm{17}$ (1927).

${ }_{13}^{10} 52 \& 53$ Vicr. c. 49 .

1320 GEO. 5 , c. 15.

${ }^{10}$ I4 GEO. 6, c. 27. Except where otherwise indicated, references hereinafter are to the Arbitration Act, r950.

${ }^{27}$ See, for example, Kursell v. Timber Operators and Contractors, 28 Com. Cas. 376 (1923), per Salter, J., at 384 .

${ }^{18}$ [I918] 2 K.B. 77 r, 778. 
I have long held a strong view as to the position which the court should adopt with regard to arbitrations. In old days there were comparatively few arbitrations and those were of a subordinate nature. Now a great part of the disputes relating to the commercial business of the country is referred to commercial arbitrators, who deal with them according to substance rather than form. In my view it would be very undesirable if many of the old rules of a somewhat technical character were invoked for the purpose of interfering with decisions of commercial arbitrators where no injury in the matter of substance has been done by the form in which those commercial arbitrators have expressed their decisions. The system which some litigants seem to favour of having, in addition to two hearings before the arbitrators and the appeal tribunal, as many hearings as they can get in the law Courts, is one which we ought not to encourage. Hence I approach the decision of this case with a desire not to interfere with the award of commercial arbitrators unless I am satisfied that substantial injustice has been done apart from a question of form.

Yet, in spite of this concern to uphold arbitration agreements and awards, one cardinal legal principle remains unimpaired: the jurisdiction of the courts cannot be wholly ousted by agreement of the parties. This principle, the most distinctive feature of the English law of arbitration, was expressed by Scrutton, L. J., in Czarnikow $v$. Roth, Schmidt \& Company, in the telling phrase, "There must be no Alsatia in England where the King's writ does not run."19

\section{B. Supremacy of the Court}

There is no parallel in the English law of arbitration to what is known in French law as "amiable composition," under which the parties bind themselves to treat the arbitration award as conclusive, and are thereby debarred from resorting to the courts. In particular, the insistence on the inalienable right of the courts to be invoked on questions of law is peculiar to the English law of arbitration; the law of Scotland resembles other legal systems in holding the parties free to make their own bargain, even if they agree to oust the jurisdiction of the court.

Yet while the court's jurisdiction cannot be ousted entirely, the obtaining of an award is often made a condition precedent to court proceedings by the insertion in the arbitration agreement of what has come to be known as a "Scott v. Avery clause." The case of Scott v.Avery ${ }^{20}$ arose out of an insurance policy, which provided for the reference of disputes to arbitration, and declared that the obtaining of the decision of the arbitrators should be a condition precedent to the maintaining of an action by the assured. The House of Lords held the clause to be valid.

Generally, therefore, a clause to this effect will ensure that the parties go to arbitration before litigation. For the court, either in the exercise of its discretion under Section $4(\mathrm{I})$ of the Act, or more generally on the ground that it is frivolous and vexatious, would normally stay an action brought in defiance of such an agreement. Where, however, the court for any reason orders that an arbitration agree-

${ }^{10}$ [1922] 2 K.B. 478,488 . Through the rapid development of administrative tribunals in the past thirty years, with no appeal to the courts except for excess of jurisdiction, Scrutton, L. J.'s apophthegm has now lost much of its force.

${ }^{30} 5$ H.L. Cas. 8II, Io Eng. Rep. II21 (H. L. I856). 
ment shall cease to have effect as regards any particular dispute, it may further order that the provision making an award a condition precedent to the bringing of an action shall also cease to have effect (Section 25(4)).

The supremacy of the court is established by its power, in proper cases, (a) to control the appointment of arbitrators, (b) to inhibit arbitration proceedings, (c) to order the statement of a special case, (d) to set aside or remit the award, and (e) to exercise control in certain other ways.

\section{Control over Appointment of Arbitrators}

While the parties are normally left to appoint their own arbitrator or arbitrators, according to the terms of their arbitration agreement, the Act gives the High Court wide powers of controlling such appointments.

The power of a party, under Section 7 , to substitute a new arbitrator or to make the arbitrator he appointed sole arbitrator in the reference, is made subject to the Court's power to set aside any such appointment.

Section 8(3) states:

At any time after the appointment of an umpire, however appointed, the High Court may, on the application of any party to the reference and notwithstanding anything to the contrary in the arbitration agreement, order that the umpire shall enter upon the reference in lieu of the arbitrators and as if he were a sole arbitrator.

Under Section 10, where a written notice served by one party on the other parties or the arbitrators to make or concur in making an appointment is not complied with, the court

may, on the application by the party who gave the notice, appoint an arbitrator, umpire or third arbitrator who shall have the like powers to act in the reference and make an award as if he had been appointed by consent of all parties.

Section I3 $_{3}(3)$ empowers the court, on the application of any party, to "remove an arbitrator or umpire who fails to use all reasonable dispatch in entering on and proceeding with the reference and making an award."

Section $23(\mathrm{I})$ provides that "where an arbitrator or umpire has misconducted himself or the proceedings, ${ }^{21}$ the High Court may remove him."

Finally, Section 25 enables the court, on the application of any party, to appoint an arbitrator or arbitrators or umpire in place of a person or persons removed by the court, and to appoint a person to act as sole arbitrator where the authority of an arbitrator or arbitrators or umpire is revoked by leave of the court, or where the court has removed a sole arbitrator or all the arbitrators or an umpire who has entered on the reference. And it further provides that "A person appointed under this section by the High Court as an arbitrator or umpire shall have the like power

\footnotetext{
${ }^{21}$ The words "or the proceedings" were first added by the Act of 1934, out of consideration for the lay arbitrator, who greatly resented that where he had failed to observe some technical rule of law he should be said to have "misconducted himself."
} 
to act in the reference and to make an award as if he had been appointed in accordance with the terms of the arbitration agreement."

\section{Inhibition of Arbitration Proceedings}

This may be effected in three ways, (I) by refusal to stay legal proceedings, (2) by leave to revoke the arbitrator's authority, and. (3) by injunction.

a. Refusal to stay legal proceedings. In England, the court has a discretion, under Section $4(\mathrm{I})$, whether or not to stay legal proceedings between the parties to an arbitration agreement. In this respect English law differs from the law of Scotland, where a submission is mandatory and the court is bound to stay an action arising out of a contract containing an arbitration clause. It is true that in most cases the English courts will stay the proceedings. As Lord Wright said, in Heyman v. Darwins, Ltd.,20

Section 4 of the Arbitration Act, r889, makes the power of the court to stay an action under the arbitration clause a matter of discretion and not ex debito justitae. Though the dispute is clearly within the arbitration clause, the court "may" still refuse to stay if, on the whole, that appears to be the better course. But the court must be satisfied on good grounds that it ought not to stay. The onus of thus satisfying the court is on the person opposing the stay, because in a sense he is seeking to get out of his contract to refer, though in truth an arbitration clause is not of strict obligation, because it is, under s.4, always subject to the discretion of the court.

There are various grounds on which the court may refuse a stay: e.g., that a charge of fraud is involved or that the arbitrator may not be impartial (Section 24), that the matters in dispute are questions of $1 \mathrm{aw}^{23}$ or of constitutional importance, ${ }^{24}$ or that not all the disputed matters are within the submission. ${ }^{25}$

If the court, in the exercise of its discretion-which is unlimited except in the cases provided for by the Arbitration Clauses (Protocol) Act, $1924^{26}$-refuses to stay an action, it in effect nullifies any simultaneous arbitration proceedings. As Fletcher Moulton, L. J., said, in Doleman \& Sons v. Ossett Corporation: ${ }^{27}$

If the Court has refused to stay an action, or if the defendant has abstained from asking it to do so, the Court has seisin of the dispute, and it is by its decision, and its decision alone, that the rights of the parties are settled. It follows, therefore, that . . the private tribunal, if it has ever come into existence, is functus officio, unless the parties agree de novo that the dispute shall be tried by arbitration, as in the case where they agree that the action itself shall be referred. There cannot be two tribunals each with the jurisdiction to insist on deciding the rights of the parties and to compel them to accept its decision. ${ }^{28}$

$x$ [1942] A.C. 356,388 .

sa Lyon v. Johnson, 40 Ch. 579 (1889).

3t Anglo-Newfoundland Development Co. v. R., [1920] 2 K.B. 214 .

${ }^{35}$ Workman v. Belfast Harbour Commissioners, [r899] 2 Ir. R. 234.

${ }^{20}$ Now $\$ 4(2)$ of the Arbitration Act, 1950.

37 [1912] 3 K.B. $257,269$.

${ }^{9}$ Aliter, where there is a chain of contracts, and the final purchaser brings an action against his seller, while the original seller relies on an arbitration clause as against his purchaser: for in such a case the respective transactions are res inter alios actae (Bruce v. Strong, [195I] 2 K.B. 447). This plurality of proceedings may be avoided where all the contracts in the chain are made subject to the rules of $\mathbf{a}$ 
To my mind this is clearly involved in the proposition that the Courts will not allow their jurisdiction to be ousted. Their jurisdiction is to hear and decide the matters of the action, and for a private tribunal to take that decision out of their hands, and decide the questions itself, is a clear ouster of jurisdiction.

b. Leave to revoke the arbitrator's authority. Section I says that the authority of an arbitrator or umpire shall be irrevocable "except by leave of the High Court or a judge thereof." The court has inherent jurisdiction to grant leave to revoke a submission (to use the more compendious, but less accurate, ${ }^{20}$ expression of the Arbitration Act, 1889), and might exercise that power where the arbitrator commits an error of law or misconducts himself. But as Tindal, C. J., said as far back as ${ }_{18} 89{ }^{30}$ " "To induce us to grant leave to revoke, a very strong case should be made out"; and with the alternative remedies provided for these cases by statute (the statement of a special case, and removal of an arbitrator or setting aside of an award for misconduct), this general power of revocation is today seldom, if ever, invoked.

More specifically, Section 24 of the Act (re-enacting Section 14 of the Arbitration Act, I934) refers to revocation of the arbitrator's authority on the ground that the arbitrator designated in the arbitration agreement is not or may not be impartial, and empowers the court to give leave to revoke the authority of an arbitrator or umpire where a dispute between the parties to the arbitration agreement involves a question of fraud.

Section 25(2) empowers the court, where it has given leave to revoke the authority of an arbitrator or arbitrators or umpire, or has removed a sole arbitrator or all the arbitrators or an umpire who has entered on the reference, to order, on the application of any party to the arbitration agreement, that the agreement shall cease to have effect with respect to the dispute referred.

c. Injunction. The court can also issue an injunction to prevent recourse to arbitration where the contract containing the arbitration clause is impeached, e.g., for fraud, mistake, or illegality; ${ }^{31}$ but that power is very sparingly used. ${ }^{32}$ It may be observed that Section 24(I) envisages application for an injunction on the ground that the arbitrator designated in the arbitration agreement is not or may not be impartial.

\section{Statement of Special Case}

Section 21 enacts:

(I) An arbitrator or umpire may, and shall if so directed by the High Court, state (a) any question of law arising in the course of the reference; or

trade association; e.g., the rules of the London Copra Association provide:

"When the subject matter and terms of contract are identical, except as to date and price, all arbitrations shall be held as between first seller and last buyer as though they were contracting parties, and the award made in pursuance thereof, subject to the right of appeal provided by the Arbitration Conditions, shall be binding upon all intermediate parties."

${ }^{28} \mathrm{Sec} \operatorname{Re}$ Smith \& Service and Nelson \& Sons, 25 Q.B.D. 545, 550, 553 (1890).

${ }^{30}$ James v. Attwood, 7 Scott 841,843 ( 1839 ).

${ }^{31}$ Kitts v. Moore \& Co., [1895] I Q.B. 253.

${ }^{32}$ Smith, Coney \& Barrett v. Becker, Gray \& Co., [1916] 2 Ch. 86. 
(b) an award or any part of an award

in the form of a special case for the decision of the High Court.

(2) A special case with respect to an interim award or with respect to a question of law arising in the course of a reference may be stated, or may be directed by the High Court to be stated, notwithstanding that proceedings under the reference are still pending.

An arbitrator or umpire may properly refuse to state a case: but he must then give the party who desires it a reasonable opportunity of applying to the court for an order directing him to do so. ${ }^{33}$

In Czarnikow v. Roth, Schmidt \& Company, ${ }^{34}$ the Court of Appeal had to consider a rule of the Refined Sugar Association, which stated,

Neither buyer, seller ... nor any other person as aforesaid shall require, nor shall they apply to the court to require any arbitrators to state in the form of a special case for the opinion of the court any question of law arising in the course of the reference, but such question of law shall be determined by arbitration in manner herein directed.

In reliance on this rule the arbitrators had refused the buyers' request to state their award in the form of a special case, or to state a case for the opinion of the court. The Court of Appeal (Bankes, Scrutton, and Atkin, L. JJ.) held the rule, and the agreement embodying it, to be contrary to public policy, and affirmed that the award must be set aside.

Bankes, L. J., said :35

Among commercial men what are commonly called commercial arbitrations are undoubtedly and deservedly popular. That they will continue their present popularity I entertain no doubt, so long as the law retains sufficient hold over them to prevent and redress any injustice on the part of the arbitrator, and to secure that the law that is administered by an arbitrator is in substance the law of the land and not some home-made law of the particular arbitrator or the particular association. To release real and effective control over commercial arbitrations is to allow the arbitrator, or the Arbitration Tribunal, to be a law unto himself, or themselves, or to give him or them a free hand to decide according to law or not according to law as he or they think fit, in other words to be outside the law.

Atkin, L. J., described the statutory jurisdiction of the court to intervene as "a provision of paramount importance in the interests of the public." He continued: ${ }^{36}$

In the case of powerful associations such as the present, able to impose their own arbitration clauses upon their members, and, by their uniform contract, conditions upon all non-members contracting with members, the result might be that in time codes of law would come to be administered in various trades differing substantially from the English mercantile law. The policy of the law has given to the High Court large powers over inferior courts for the very purpose of maintaining a uniform standard of justice and one uniform system of law.

A party to an arbitration agreement is, moreover, entitled at any stage of the

${ }^{33}$ Willers, Engel \& Co. v. Nathan \& Co., Ltd. 30 Lloyd's List L. R. 208 (1928).

34 [1922] 2 K.B. 478.

${ }^{36}$ Id. at 484 .

${ }^{30} \mathrm{Id}$. at $49 \mathrm{r}$. 
proceedings to require that a case be stated for the opinion of the Court. In $\operatorname{Re}$ Fischel \& Co. and Mann \& Cook, ${ }^{37}$ the Divisional Court set aside the award of an umpire who had refused the buyers' request to state a case, basing his refusal on the ground that under the rules of the General Produce Brokers' Association of London his award could be taken up to the Association's Committee of Appeal. Salter, J., said: ${ }^{38}$

When the parties to a contract insert in it an arbitration clause, they elect a tribunal which has its obvious advantages and its equally obvious disadvantages. Its advantages consist in the rapidity of its procedure and its familiarity with the business to which the contract relates; and one of its chief disadvantages consists in its inability to decide the questions of law which are bound to arise before it with the same precision with which they can be decided by a court of law.

It is clearly advantageous at times that the opinion of the court on a question of law raised in the arbitration proceedings should be obtained as early as possible. If, for instance, it should happen that the arbitration agreement is not binding, it would be a waste of time, money, and effort to go through all the stages of arbitration before ascertaining that in point of law the award cannot stand.

\section{Remission or Setting Aside of Award}

a. Remission. Section 22(x) enacts: "In all cases of reference to arbitration the High Court or a judge thereof may from time to time remit the matters referred, or any of them, to the reconsideration of the arbitrator or umpire."

The grounds for remitting an award were stated by Chitty, J., in Re Montgomery, Jones \& Co. and Liebenthal \& Co., ${ }^{39}$ to be as follows:

(I) that the award is bad on the face of it;

(2) that there has been misconduct on the part of the arbitrator;

(3) that there has been an admitted mistake and the arbitrator asks that the matter may be remitted; and

(4) where additional evidence has been discovered after the making of the award.

To these must be added, in view of Absalom, Ltd. v. Great Western (London) Garden Village Society; Ltd. ${ }^{40}$

(5) when disputes are referred to an arbitrator in which a question of law becomes material, and an error of law appears on the face of the award.

b. Setting aside. The court has inherent jurisdiction to set aside an award which is bad on its face (i.e., where a material error of law or of fact appears on the face of the award), or which is in excess of the arbitrator's authority, or is not certain and final on all matters requiring the arbitrator's decision. This jurisdiction may also extend to cases where new material evidence is discovered, though that is more properly a ground for remission. ${ }^{41}$

In addition, Section $23(2)$ provides: "Where an arbitrator or umpire has mis-

${ }^{37}$ [1919] 2 K.B. 43I.

${ }^{30} 78$ L. T. 406,407 (K.B. 1898 ).

${ }^{38} 7 d$. at 442 .

10 [1933] A.C. 592.

«1 Re Keighley, Maxsted \& Co., and Bryan Durant \& Co., [1893] I Q.B. 405. 
conducted himself or the proceedings, or an arbitration or award has been improperly procured, the High Court may set the award aside."

It will be observed that there is a considerable overlap between the grounds justifying remission and setting aside of an award, and it is often a matter of considerable difficulty to decide whether an award should be remitted for reconsideration or whether it should be wholly set aside. ${ }^{42}$ The court would normally prefer to remit an award, if any useful purpose would be served thereby, and frequently makes an order of remission on a motion to set aside. Where, however, the arbitrator or umpire has been guilty of such misconduct (e.g., corruption or defiance of the law) as to have forfeited the confidence of the court, the award will certainly be set aside and not remitted to him.

The rule that an award may be remitted or set aside for an error of law on its face applies only where the point of law arises incidentally in the course of the reference. Where a question of law is specifically referred to arbitration, the decision on that question is as binding and unappealable as a finding of fact. As Lord Cave said, in Government of Kelantan v. Duff Development Co., Ltd.,

No doubt an award may be set aside for an error of law appearing on the face of it; and no doubt a question of construction is (generally speaking) a question of law. But where a question of construction is the very thing referred for arbitration, then the decision of the arbitrator upon that point cannot be set aside by the court only because the court would itself have come to a different conclusion. If it appears by the award that the arbitrator has proceeded illegally, for instance, that he has decided on evidence which in law was not admissible, or on principles of construction which the law does not countenance, then there is error in law, which may be ground for setting aside the award; but the mere dissent of the court from the arbitrator's conclusion or construction is not enough for that purpose.

Whether a question is one of law or of fact can, of course, be very difficult to determine. In Mehmet Dogan Bey v. G. G. Abdeni \& Co., ${ }^{44}$ it was contended that remoteness of damage was a question of law, or at least a question of mixed law and fact, on which an arbitrator's conclusions could be challenged; but McNair, J., held to the contrary, saying $:^{45}$

I may add that if this dispute had been tried in the Commercial Court, as it might have been, with the assistance of a City of London special jury, I can imagine no question more proper to be put to such a jury than the question whether this particular form of loss, namely, damages resulting from the devaluation of the pound sterling, was reasonably foreseeable by commercial men on July 8, r949, and if the jury, properly directed, had answered the question in the negative, as the learned arbitrator did here, then their verdict would not, in my judgment, be open to challenge.

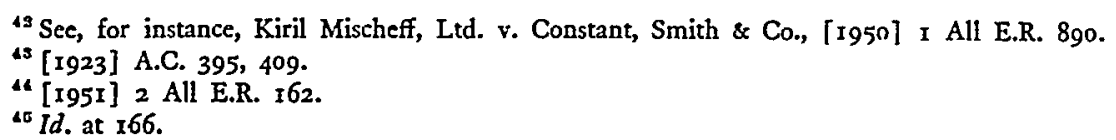




\section{Other Forms of Control by the Court}

To complete this account of the supremacy of the court, it remains only to mention some miscellaneous powers vested in the court by statute.

Under Section I2(6) the High Court has, for the purpose of a reference, the same power of making orders in respect of security for costs, discovery, and interrogatories, the preservation or inspection of property, and various other such matters, as it has in relation to a High Court action.

Section $x_{3}(2)$ enables the court to enlarge the time limited for making an award, whether that time has expired or not.

Section 27 empowers the court, where the arbitration agreement provides that claims shall be barred unless proceedings are commenced within a fixed time, to extend that time, in case of undue hardship, "for such period as it thinks proper."

Where an arbitrator or umpire refuses to deliver his award except on payment of the fees demanded by him, Section I9(I) provides that the court may, on application, order him to deliver the award to the applicant on payment into court of the fees demanded, and may order that those fees be taxed by the taxing officer. This provision ensures that an award is not withheld pending a dispute over the arbitration fees.

Finally, Section 26 provides that an award on an arbitration agreement may "by leave of the High Court or a judge thereof" be enforced in the same manner as a judgment or order. ${ }^{46}$ Thus the court has the last word, in that it can refuse to enforce an award where, for example, the validity of the award is doubtful, and in certain other cases.

It may be seen, then, that at every stage of arbitration proceedings, from their inception to their final determination, the court has overriding powers which may be invoked by any party who has reason for dissatisfaction.

\section{Extent to Which Arbitration Agreements Remain Binding}

In considering whether legal proceedings ought to be stayed, the courts have had some difficulty in determining the conditions under which an arbitration agreement may continue to be binding on the parties although the contract which incorporated it has been repudiated or frustrated.

The authorities were reviewed by the House of Lords in Heyman v. Darwins, Ltd. ${ }^{47}$ The contract under consideration provided: "If any dispute shall arise between the parties hereto in respect of this agreement or any of the provisions herein contained or anything arising hereout the same shall be referred for arbitration. ..." A dispute having arisen between the parties, the appellants commenced an action against the respondents, alleging that they had repudiated the contract: and the respondents, denying the repudiation, applied to have the action stayed in order that it might be dealt with under the arbitration clause. It was held that the

10 The court has a similar discretion in respect of foreign awards, under $\$ 37$.

'7 [1942] A.C. 356,357 . 
dispute fell within the terms of the arbitration clause, and that the action should be stayed. Viscount Simon said: ${ }^{48}$

If the dispute is whether the contract which contains the clause has ever been entered into at all, that issue cannot go to arbitration under the clause, for the party who denies that he has ever entered into the contract is thereby denying that he has ever joined in the submission. Similarly, if one party to the alleged contract is contending that it is void ab initio (because, for example, the making of such a contract is illegal), the arbitration clause cannot operate, for on this view the clause itself also is void. But, in a situation where the parties are at one in asserting that they entered into a binding contract, but a difference has arisen between them whether there has been a breach by one side or the other, or whether circumstances have arisen which have discharged one or both parties from further performance, such differences should be regarded as differences which have arisen "in respect of," or "with regard to" or "under" the contract, and an arbitration clause which uses these, or similar, expressions should be construed accordingly.

\section{Lord Macmillan said:49}

I venture to think that not enough attention has been directed to the true nature and function of an arbitration clause in a contract. It is quite distinct from the other clauses. The other clauses set out the obligations which the parties undertake towards each other hinc inde, but the arbitration clause does not impose on one of the parties an obligation in favour of the other. It embodies the agreement of both parties that, if any dispute arises with regard to the obligations which the one party has undertaken to the other, such dispute shall be settled by a tribunal of their own constitution. And there is this very material difference, that whereas in an ordinary contract the obligations of the parties to each other cannot in general be specifically enforced and breach of them results only in damages, the arbitration clause can be specifically enforced ${ }^{50}$ by the machinery of the Arbitration Acts. The appropriate remedy for breach of the agreement to arbitrate is not damages, but its enforcement. Moreover, there is the further significant difference that the courts in England have a discretionary power of dispensation as regards arbitration clauses which they do not possess as regards the other clauses of contracts.

Although Lord Wright observed ${ }^{51}$ that the effect of frustration on an arbitration clause was a question still open for decision in the House of Lords, and did not arise in the present case, the views expressed by their Lordships (including Lord Wright himself) on this question leave no doubt that unless an arbitration clause is phrasea restrictively it will continue to be effective after frustration of the contract containing it.

In Woolf $v$. Collis Removal Service, ${ }^{52}$ the plaintiff had contracted with the defendants to store his goods in their warehouse. The contract contained a clause requiring any claims or counterclaim by the customer (but not claims by the warehousemen) to be submitted to arbitration, and making an award a condition prece-

${ }^{48}$ Id. at 366 .

${ }^{\circ 9}$ Id. at $373-374$.

${ }^{\text {Eo }}$ Specifically enforced, that is, by indirect means: as Fletcher Moulton, L.J., put it, "The law will not enforce the specific performance of such agreements, but, if duly appealed to, it has the power in its discretion to refuse to a party the alternative of having the dispute settled by a court of law, and thus to leave him in the position of having no other remedy than to proceed by arbitration." (Doleman \& Sons v. Ossett Corporation, [1912] 3 K.B. 257, 268-269).

${ }^{61}$ [1942] A.C. 356,383 .

${ }^{52}$ [1948] I K.B. I1. 
dent to any right of action. It was alleged that the goods were damaged by storage in a disused piggery, and the plaintiff issued a writ claiming damages for breach of contract and/or negligence. The Court of Appeal affirmed the order to stay the action, holding ( $\mathrm{I}$ ) that an arbitration clause, even when unilateral, could not be treated as on the same footing as an "exceptions clause" (of which a carrier or warehouseman loses the benefit by "deviation"), and (2) that the alternative claim in negligence did not take the plaintiff's claim out of the arbitration clause, the contractual obligation of diligence being co-extensive with the non-contractual obligation, and the claim in tort being covered by the term "claims" in the arbitration clause.

\section{III}

\section{Commercial Aspects of English Arbitration $\dagger$}

\section{A. The Range of Arbitration}

\section{Number of Arbitrations}

In spite of the numerous grounds on which an application to the court may be entertained, arbitrations in which the court is ever asked to intervene form a minute proportion of the total number of arbitrations.

It is impossible to obtain statistics for the country as a whole. But the fact that before the war some 20,000 arbitrations were held each year under the rules of the London Corn Trade Association alone ${ }^{53}$ may afford some idea of the total volume of arbitration.

Not the least difficulty in seeking to assess the volume of arbitration is the complex manner in which it varies with changes in the conditions of trade. On the one hand, governmental restrictions due to the international schism have reduced the total amount of trade, and government bulk buying has made for fewer transactions: the result of these factors has been a marked diminution, in postwar years, of those "quality/condition" arbitrations which form the majority of commercial disputes, as well as the total suspension of arbitration proceedings by such bodies as the Liverpool Corn Trade Association, the London Flour Trade Association, and the Imported

†The following information has been mainly collected from the answers to a detailed questionnaire, which was sent to some forty trade associations and similar institutions, and from the standard contract forms and other documents which were forwarded in reply by many of these bodies. Grateful acknowledgment is made to the Registrar of the London Court of Arbitration, the Secretary of the Institute of Arbitrators, the Clerk to the Committec of Lloyd's, the Secretaries of the Birmingham, Bradford, Liverpool and Shefficld Chambers of Commerce, the Airbrokers Association, the Baltic Mercantile and Shipping Exchange, the British Insurance Association, the British Motor Trade Association, the Chamber of Shipping of the United Kingdom, the Hide and Skin Shippers and Agents Association, the Imported Meat Trade Association, the Incorporated Oil Secd Association, the Institute of Chartered Shipbrokers, the Liverpool Corn Trade Association, the Liverpool Cotton Association, the Liverpool Provision Trade Association, the London Cattle Food Trade Association, the London Copra Association, the London Corn Trade Association, the London Flour Trade Association, the London Jute Association, and the London Oil and Tallow Trades Association, the Legal and Parliamentary Secretary of the Association of British Chambers of Commerce, and the Assistant Secretary of the Stock Exchange.

${ }^{2}$ See the statistics furnished by 2 number of trade associations to the Committec on Commercial Arbitration of the International Law Association: ReporT of THE Throty-Ninty Conference (PAris, 1936). 
Meat Trade Association. On the other hand, the hazards involved in postwar trading, such as the sudden impositions of export restrictions and duties, and violent fluctuations of price, have occasioned-not only in proportion to the reduced volume of trade, but even absolutely as compared with the prewar figures-a considerable increase in the number of "technical" arbitrations, and, significantly enough, in the proportion of "special cases" arising out of them.

\section{Arbitration Bodies}

Another, and insurmountable, difficulty in the way of assessing the total number of arbitrations is the variety and multiplicity of arbitration tribunals.

It is not possible to enumerate all the institutions in England which provide machinery for arbitration. There are two bodies, however, which fall into a special category as institutions brought into existence for the purposes of arbitration, ${ }^{55}$ and which therefore merit separate treatment.

The London Court of Arbitration was formed in 1892 as an impartial bodyadministered jointly by the Corporation of London and the London Chamber of Commerce-which is prepared to appoint arbitrators at the the request of disputants, and to provide the machinery, as well as the venue, for arbitration. The Court, which has a permanent Registrar (a non-lawyer), maintains a panel of arbitrators classified according to professions and trades, and can call upon the services of experts for whatever dispute may be submitted. Its services are available to any person or organization in any part of the world. Reference to the Court may be made by previous insertion in the contract of a clause to the effect that "the construction, validity and performance of this contract shall be governed by the law of England and all disputes which may arise under, out of, or in connection with this contract shall be submitted to the arbitration of the London Court of Arbitration under and in accordance with its Rules at the date hereof"; or, of course, the parties may sign an arbitration agreement to that effect after the dispute has arisen. Two rules of special interest may be quoted:

20. Notwithstanding anything in these Rules, where in any arbitration a question arises as to the price of goods at a particular date in some place other than that in which the arbitration is held, it shall be competent to the arbitrator, arbitrators or umpire to invite the Chamber of Commerce of such other place, or any trade organisation or Government official to furnish him or them with a certificate of such price on such date and he or they shall be entitled to receive such certificate in evidence without other proof than the signature of the responsible official of such Chamber of Commerce or trade organisation or of such Government official.

44. Where goods have been sold and resold on two or more occasions and the same, or substantially the same dispute arises on more than one contract of sale, it shall be competent for the arbitrator, arbitrators or umpire appointed to determine any one such

* All disputes that do not relate to quality and condition are, in the language of commercial men, "technical."

${ }^{6 E}$ The International Chamber of Commerce, of course, also comes into this category; but its operations in England are outside the scope of this article. 
dispute to invite the parties to any other such dispute to join in the arbitration to the end that all such disputes may be determined at the same time by means of an arbitration between the first seller and the last buyer. ${ }^{56}$

The London Court of Arbitration is of considerable value to disputants who are not members of a trade association with its own arbitration machinery.

The other arbitration body is the Institute of Arbitrators, which was founded in IgI5 and incorporated in I925. Like the London Court of Arbitration, it maintains a panel of arbitrators from which specialists in particular fields can be chosen. It is, however, concerned more with building and engineering than with trade disputes. The provision of arbitrators is only one of the Institute's functions. It aims to promote and improve the practice of arbitration, and to train arbitrators by means of discussion meetings, lectures and examinations, practice arbitrations, and the publication of a quarterly journal. The Institute can, moreover, claim some credit for important amendments of arbitration law; for it was with the Institute's backing that its President (Lord Askwith) introduced in the House of Lords a Bill, based on the MacKinnon Committee's recommendations, which became law as the Arbitration Act, I934.

In addition to these special arbitration bodies, some of the larger provincial chambers of commerce afford arbitration facilities, both locally for general purposes and more widely in their specialized fields, such as the wool arbitrations under the auspices of the Bradford Chamber of Commerce, to which merchants from overseas frequently have recourse.

A considerable number of arbitrations, too, take place outside the bounds of any institution (and their frequency cannot therefore be estimated). Into this category (which may for convenience be called "private arbitrations") fall the majority of building and engineering disputes, of disputes between insurance companies and their policy-holders, and between businessmen who do not choose to invoke the assistance of a chamber of commerce or a trade association.

The great majority of arbitrations, however, are carried on within the trade or mercantile associations, and it is with this kind of arbitration that we are mainly concerned. The trade associations are able to offer their members, and others who resort to their arbitration rules, the advantages of speedy and inexpensive adjudication, in private, by persons experienced in the trade. Many of them make up standards (e.g., of cotton, of linseed, of grain) which the arbitrators can compare with samples of disputed shipments which are sent under seal from all parts of the world; many of them, too, have official analysts, whose certificate on certain points (e.g., admixture of foreign matter) is final and conclusive. Thus quality/condition arbitrations can be disposed of very expeditiously, and it is seldom that such arbitrations are taken up to the appeal committee of the trade association, and hardly ever (except where the right of rejection is claimed) that they come to the cognizance of the courts.

${ }^{56}$ Cf. note 28 supra. 
In some few cases, too, the trade association can bring pressure to bear on a recalcitrant party who refuses to abide by the award. ${ }^{57}$

\section{B. The Submission ${ }^{58}$}

In English law, no formalities whatever are required for a submission to arbitration. Even an oral submission is perfectly valid (and is indeed customary in some trades) : but it is not covered by statute, so that the award would not be enforceable.

A written submission need not be embodied in a formal document; it may even be constituted by an exchange of letters between the parties. It need not specify the matters in dispute, nor name the arbitrators. In this respect English law is much more elastic than many foreign codes, which lay down precise formalities, sometimes involving notarial certification, for arbitration agreements.

Moreover, in English law an agreement to submit future, as well as existing, differences to arbitration is perfectly valid. It is this which has made it possible for arbitration clauses to be inserted in the standard forms of contract issued by the multifarious trade associations for use in all parts of the world.

A submission which stated merely that "the parties agree to refer all disputes under this contract to arbitration" would be quite effective, as it would automatically attach to itself the whole machinery of implementation contained in the Arbitration Act, I950. For several reasons, however, the arbitration clauses of trade association contracts do not rest content with this. In the first place, businessmen like to know exactly what they are letting themselves in for, and would hardly be satisfied (particularly if they live outside England) by a reference, express or implied, to the Arbitration Act. Secondly, the trade associations want rules of their own making, adapted to their particular needs, rather than rules giving the court the same limited powers for arbitrations of every kind. They prefer to keep in their own hands those powers which in the absence of special provisions in the submission are vested in the court-in particular, the power to appoint arbitrators (or an umpire) in default of appointment by the parties (or arbitrators). Indeed some of the associations keep the power of appointment exclusively to themselves, and do not allow the parties any choice in the matter. Again, the trade associations commonly provide for appeals to their own committees from the decision of arbitrators or umpire, which in the absence of special provisions for appeal in the arbitration clause would be final and unappealable. Finally, by their consent to the arbitration clause the parties can be

\footnotetext{
${ }^{67}$ It may be convenient to note here that it is sometimes provided (as in the arbitration rules of the Bradford Chamber of Commerce) that 'No party to a reference under these rules shall bring any action or commence or prosecute any proceedings ... against any other party to the reference, concerning the matters referred or any of them." Though legally inoperative, as we have seen, such a clause no doubt tends to discourage litigation, and its commercial effectiveness should therefore not be underestimated (it is a fact that out of the thousand arbitrations held under the rules of the Bradford Chamber of Commerce since 1890 , there has not been a single appeal to the courts from an award).

${ }^{68}$ The Articles or Rules of some associations contain an undertaking by members to submit their disputes to arbitration. Though breach of this undertaking might lead to expulsion or some other penalty, it does not, of course, constitute a "submission," which must be inter partes.
} 
bound to accept relaxations of the rules of evidence and procedure ${ }^{60}$ which in the absence of such acceptance would open the door to the intervention of the courts.

\section{Arbitration Tribunals}

\section{Tribunals of First Instance}

Outside the trade associations, most references are made to a single arbitrator, who is either agreed upon by the parties or, in default of agreement, is appointed (in accordance with the terms of the submission) by some independent person of authority, such as the president of a professional institute. This is undoubtedly the speediest and most inexpensive method of arbitration.

In many branches of commerce, however, it is customary to provide for the appointment of an arbitrator by each party, the two arbitrators appointing an umpire if and when they disagree. [It may be observed that Section 20, incorporating an amendment introduced by Section 5 of the Arbitration Act, x934, provides that unless a contrary intention is expressed in the arbitration agreement, the two arbitrators shall appoint an umpire immediately after they are themselves appointed.] This practice has been frequently criticized as dilatory and expensive; ${ }^{00}$ but it is difficult to conceive of a more satisfactory method when the parties live in distant parts of the world, and desire to be assured that the points in their favor are adequately put forward at the arbitration in England. Commercial arbitrators are partly advocates. ${ }^{61}$ Indeed, it is not unusual for the same arbitrator to be appointed habitually by an overseas merchant who is engaged in frequent trade disputes.

Methods of appointment, however, are infinitely various. Three examples must suffice to illustrate this variety. In the London Jute Association, the two arbitrators (and if necessary the umpire) are appointed-in the case of quality arbitrationsby the Arbitration Tribunal of the Association: the arbitrators inspect the sample bales and make their finding without knowing who the buyers and sellers are. In the case of technical arbitrations, the Chairman appoints two arbitrators (and if necessary the umpire), but the parties may appoint their own trade representatives to appear before them.

The Stock Exchange has three kinds of arbitration tribunals. A Rules and Disputes Committee of 18 members hears disputes between members, and then passes a resolution subject to the confirmation of the Stock Exchange Council; the Council

${ }^{50}$ The arbitration rules of the Bradford Chamber of Commerce, for example, provide: "The Arbitrator, Arbitrators, or Umpire may adopt such procedure or methods and admit such evidence as he or they may think fit for the purposes of arriving at a correct decision. It shall be in the absolute discretion of the Arbitrator, Arbitrators, or Umpire to decide whether the subject matter of a dispute can best be dealt with by receiving the written statements of the parties thereto, together with such documents as they may desire to lay before the Tribunal, or whether the evidence of witnesses shall be heard upon any matter submitted. If he or they decide to hear such evidence he or they may in his or their absolute discretion hear it in the absence of the other Party to the dispute and in the absence of the witnesses of such other Party" [this last sentence confers unusual powers].

${ }^{\circ}$ E.g., by MacKinnon, L. J., The Times, March 5, 1931.

or "Generally very indifferent advocates," per MacKinnon, L. J., supra. But the contrary vicw is expressed by Mr. Cyril Miller, in The Journal of the Institute of ARbitrators (Incorporated) (June, I938). 
itself considers claims by non-members against members; and disputes between members which do not affect the general interests of the Stock Exchange are referred to the arbitration of a member or members of the Stock Exchange (in which case the parties usually each appoint an arbitrator, and the arbitrators appoint an umpire in the usual way).

The British Motor Trade Association has a Court of Arbitration which is appointed by the Secretary of the Association; ${ }^{62}$ it consists of a legal Chairman (who is selected from a panel of retired Colonial judges retained by the B.M.T.A.) and two other members (selected from the Council and from persons nominated by the Council to the Appeal and Price Protection Committees of the Association).

\section{Appeal Tribunals}

In private arbitrations the decision of the arbitrator or umpire is final. Nearly all the trade associations, however, provide machinery for appeal. Usually there is a committee of appeal from which an ad hoc Board of Appeal is elected, care being taken to ensure that no member of the Board is in any way connected either with the parties to the dispute or with the arbitrators or umpire. The Liverpool Cotton Association has a most unusual two-tiered appeal in certain types of cases. Its Rules provide:

When an appeal on quality or damp has been heard by the appropriate Appeal Committee, and an award has been duly made by such Committee, either of the parties to the matter in dispute shall have the right to apply to the Directors for leave to appeal further by way of Super-Appeal on the ground that an error has been made by the Appeal Committee, provided such right be claimed before noon on the first business day following the date of the Appeal Award in the case of Docket Cotton and Cotton sold on Spot Terms, and before noon on the third day following the date of the Appeal Award in the case of Cotton sold on C.i.f. terms and other similar terms.

If on an application under Rule $6_{5}$ the Directors decide that a prima facie case of error has been made out they shall grant leave to appeal further and shall forthwith appoint an Ad Hoc Committee consisting of five disinterested Members of the Association (whether Directors or not) to hear the Super-Appeal.

It is usual under trade association rules to provide that the award of the arbitrators or umpire shall be confirmed unless all, or all but one, of the Board of Appeal are in favor of varying it.

\section{The Conduct of Arbitrations}

The procedure in arbitration varies from the "feel of the grain" by one or two experienced corn trade arbitrators at one end of the scale to the quasi-judicial proceedings of a full-scale shipping arbitration at the other.

In the general run of arbitrations, especially among commercial men, there is a relaxation of the legal rules of procedure and evidence; and even where this relaxation is not explicit in the submission, the parties will be deemed to have agreed to any deviation from legal standards to which they raise no objection at the time.

\footnotetext{
-2 The Secretary of the B.M.T.A. is a lawyer; so too are many of the Managers of the shipping Mutual Defence Associations. Otherwise, legal qualifications are unusual in a trade association executive.
} 
It is not only in matters of evidence and procedure that this laxity is permitted. Even that most substantial rule of "natural justice," that a man must not be "judge in his own cause," can be ignored by agreement of the parties. Indeed it is quite common in building contracts for the contractor to bind himself to arbitration by the building owner's architect or engineer.

Again, although "an 'advocate-arbitrator' is a contradiction in terms" (as the General Council of the Bar has ruled for the guidance of barristers ${ }^{63}$ ), it is generally accepted that commercial arbitrators act as advocates for the parties who appoint them. As Farwell, L. J., said, in Re Enoch and Zaretzky, Bock \& Co., ${ }^{04}$

Where a case is referred to two arbitrators and an umpire, it is well understood that the arbitrators act as counsel who try and settle the case without going into Court; but the umpire or a single arbitrator occupies a judicial position and exercises judicial powers, and is bound, as far as practicable, to follow legal rules. ...

Similarly, in French Government v. Owners of S. S. Tsurushima Maru, ${ }^{\text {of }}$ the Court of Appeal recognized the practice of commercial arbitrators to present the evidence and arguments of the parties to the umpire.

In Bourgeois v. Weddell \& Company, ${ }^{66}$ it was held that an arbitrator might be called by the party who had appointed him to give evidence before the umpire. Lush, J., said: $:^{67}$

An arbitrator may act now in commercial arbitrations as an advocate and as an agent for the party who appoints him. I think that the true view is that when the arbitrators in a commercial arbitration have differed and the umpire has taken upon himself the burden of adjudication, each arbitrator may be and is regarded as no longer acting judicially but as a person who is entitled either to advocate the cause of the party who appointed him or to give evidence in support of that cause.

Sankey, J., said: $:^{\text {8 }}$

Under the modern system of conducting arbitrations great inroads have been made upon what was thought to be the legal practice of arbitration. There is now a difference between arbitrations conducted as legal arbitrations and arbitrations conducted as commercial arbitrations. ...

With regard to an arbitrator being a witness, certainly in many cases the position is as follows. In the case, say, of perishable goods landed from a vessel on to the quay-side, the arbitrators are selected; they go down and look at the goods, the goods may be then destroyed, and the only persons who can speak as to the quality of the goods are the two arbitrators. They may have acquired their knowledge either before or after they were appointed as arbitrators, but in either case I cannot think it is the law that if they should unfortunately disagree they would not be able to be called as witnesses before an umpire and depose to the facts. It may be regrettable that the strict rule should be relaxed, but I think it is too late to question it now.

${ }^{\text {a }}$ Annual Statement of the General Council of the Bar il (1933).

os [rgro] I K.B. 327, 334. 37 T.L.R. 96I (r921).

[1924] I K.B. 539 .

${ }^{\circ \pi}$ Id. at 546 .

${ }^{68}$ Id. at 547 . 


\section{E. The Place of Lawyers in Arbitration}

Whether as arbitrator or as advocate, the lawyer is seldom called upon to take part in arbitration proceedings. In some private arbitrations, a lawyer might be agreed upon by the parties. But in general, it is only in cases involving issues of law or very large sums of money (such as shipping disputes) that a lawyer is chosen to adjudicate.

Under Lloyd's Salvage Agreement, the arbitrator is selected by the Committee of Lloyd's from a panel of Queen's Counsel practicing in the Admiralty Division, the senior member of the panel acting as Appeal Arbitrator. ${ }^{69}$ In commercial disputes between shipowner and charterer, there are normally two commercial arbitrators, who sometimes appoint a lawyer as umpire. ${ }^{70}$

In other types of commercial arbitration, lawyers are seldom employed as arbitrators or umpire (though a Committee of Appeal might have the association's solicitor at hand to advise them on points of law raised by counsel, e.g., in stating a case for the court, and the solicitor might be consulted in a complicated case to advise on the form of the award). Indeed, trade association rules generally provide that the arbitrators or umpire shall be members of the association; there is thus no possibility of a lawyer being employed in that capacity.

Some associations will not permit lawyers to be employed in any capacity at their arbitrations. Thus Rule 56 of the Liverpool Cotton Association states:

No party to an arbitration or an appeal or a super-appeal shall be entitled to be represented by a solicitor or counsel or to have any solicitor or counsel present on his behalf upon the hearing of any arbitration, appeal or super-appeal.

The London Cattle Food Trade Association's rules do not envisage legal representation at first instance, but Rule 9 provides:

Each party to an appeal shall state his case either verbally or in writing and appear either personally or by an agent engaged in the trade and duly appointed in writing, but shall not be represented or appear on the hearing of such appeal by counsel or solicitor unless special leave shall have previously been obtained in writing from the Board of Appeal, which leave the Board of Appeal may grant or refuse in their sole discretion and without assigning any reason.

The London Oil and Tallow Trades Association is somewhat more specific, Rule 6 stating:

The parties to an arbitration or to an appeal to the Board of Appeal shall not be represented or appear on the hearing of such arbitration or appeal by counsel or solicitor unless in the sole discretion of the arbitrators, or umpire, as the case may be, or Board of Appeal, the case is of special importance or questions of law are likely to arise upon which the opinion of the High Court of Justice may be required.

\footnotetext{
${ }^{69}$ Lloyd's Arbitration Agreement in cases of Collision has for some reason not won acceptance, and collision disputes are heard in the Admiralty Division of the High Court.

${ }^{70}$ The Australian Grain Charter, however (as agreed between the Australian Wheat Board, the Ministry of Food, and the Chamber of Shipping of the United Kingdom), states categorically: "The Arbitrators and Umpire shall be commercial men."
} 


\section{F. The Award}

The trade associations provide that the award shall be made on the association's official form (for which a small fee is charged). Where the parties appoint their own arbitrators, the application for the form may be the association's only intimation that an arbitration has taken place under its rules.

Unless the award is stated in the form of a special case, it is very unusual for it to state reasons, as this may so easily afford the dissatisfied party access to the court. Occasionally, at the request of a party, reasons are given in a separate document-a practice which perhaps opens the door to intervention by the court to a greater extent that many arbitrators fondly suppose. ${ }^{71}$ Usually, the reasons for an award only emerge when the umpire states them to the Appeal Committee (on which occasion the arbitrators again act as advocates for the parties who appointed them).

It is only in a very small proportion of arbitrations that the tribunal is asked to "state a case." The party asking for it should then be required to formulate the precise questions upon which the decision of the court is desired. ${ }^{72}$

Whether the opinion of the court is sought by the statement of a "consultative case" (under Section $2 \mathrm{x}(\mathrm{I})(\mathrm{a})$ ) or by an award in the form of a special case (Section 2I (I) (b)) generally depends on all the circumstances. It is interesting to note, however, that at least one trade association, the Incorporated Oil Seeds Association, always prefers to state a consultative case; the reason for this preference is that the statement of a consultative case leaves the final decision with the Board of Appeal and not with the court, and as a matter of policy the Association desires its own Appeal Committee to be regarded as "the House of Lords" in arbitrations arising out of its standard contracts.

Awards, unlike judgments, cannot generally form precedents. Not only is the ratio decidendi not given; for the most part awards are only known to the parties and the arbitrators, and, in the case of a trade association, to the secretary, who files an office copy. In a very few cases, however (e.g., in the London Jute Association and the Liverpool Cotton Association), earlier awards may be referred to by arbitrators for such meagre assistance as they may afford in a subsequent dispute. If an association desires to have a point of law clarified-and this applies mainly to the shipping Mutual Defence Associations, which require authoritative rulings on the construction of phrases in the standard charterparties-a case will be stated for the High Court, and a binding legal precedent will be thus established (often resulting in an amendment of the document in question).

${ }^{71}$ See Re Dare Valley Railway Co., L.R. 6 Eq. 429 (1868); Re Brandt \& Co. and Boutcher \& Co., 7 T.L.R. I40 (I890).

${ }^{2} 2$ Williams v. Manissalian Frères, 23 Com. Cas. 42 (1923). However, "where an umpire states a case in the form that subject to any questions of law he finds the facts so-and-so, and awards so-and-so, the parties are entitled to take any questions of law that arise upon those facts." Hudson's Bay Co. v. Domingo Munbon S.A. (1922), Io Lloyd's List L. R. 476, 479, per Atkin, L. J.; cf. Minister of Food v. Reardon Smith Line, (I95I) 2 T.L.R. 1158. 
G. Discrepancies Between Commercial and Legal Notions

The views of businessmen and lawyers are often at variance. Three examples of this were cited by Scrutton, L. J., who said, in Hillas \& Co., Ltd.v. Arcos, Ltdd ${ }^{73}$ :

... I regret that in many commercial matters the English law and the practice of commercial men are getting wider apart, with the result that commercial business is leaving the courts and being decided by commercial arbitrators with infrequent reference to the courts. Commercial men carry on an enormous mass of business under the system of "string contracts," under which $\mathrm{A}$, who has made a contract with $\mathrm{B}$, goes to arbitration with $Z$, of whom he never before heard and with whom he has in the eyes of the law no contractual relations. Their view of damages as a sufficient remedy for breach of contract entirely differs from the law's remedy of rejection. The commercial man does not think there can be no contract to make a contract when every day he finds a policy "premium to be agreed" treated by the law as a contract.

In Ronaasen v. Arcos, $L t d .{ }^{74}$ Wright, $\mathrm{J}$., set aside the award of an umpire who had found that the timber tendered, although not strictly within specification, was near enough to be commercially within it, and to be of equal value, and who had therefore held the buyers disentitled to reject. On appeal to the House of Lords, Lord Atkin said: ${ }^{75}$

I do not myself think that there is any difference between businessmen and lawyers on this matter. No doubt, in business, men often find it unnecessary or inexpedient to insist on their strict legal rights. In a normal market, if they get something substantially like the specified goods they may take them with or without grumbling and a claim for an allowance. But in a falling market I find that buyers are often as eager to insist on their legal rights as courts of law are ready to maintain them. No doubt at all times sellers are prepared to take a liberal view as to the rigidity of their own obligations, and possibly buyers who in turn are sellers may also dislike too much precision. But buyers are not, as far as my experience goes, inclined to think that the rights defined in the [Sale of Goods Act] are in excess of business needs.

It is submitted that Lord Atkin hit the nail on the head. Commercial men may regard the law as unduly technical and inelastic for their purposes so long as trade is brisk, or at any rate steady: but when markets fluctuate or droop, and they stand to lose more than they can afford, they are more willing to stand on their legal rights. Hence the significant increase in the number of "technical" arbitrations and special cases noted above.

\section{IV}

\section{ConcLusion}

It is probable that the advantages of arbitration have been to some extent underestimated by lawyers and exaggerated by commercial men. So far as disputes on quality are concerned, it cannot be doubted that arbitration is infinitely preferable to litigation; and similarly, where trade practices are concerned, a reference to arbitration will save the trouble and expense of proving to a judge what is well

\footnotetext{
${ }^{83} 36$ Com. Cas. 353,368 (r93I).

${ }^{74}{ }_{48}$ T.L.R. 356 (I932).

${ }^{75}$ Sub nom., Arcos, Ltd. v. Ronaasen, [r933] A. C. $470,480$.
} 
known to persons engaged in the trade. ${ }^{70}$ For the determination of questions of law, however, arbitration is of more dubious value. It is true that questions of law are seldom unencumbered by disputes of fact; and in such cases commercial arbitrators serve a valuable purpose in finding the true facts in the light of their expert knowledge, and so presenting to the court, by way of special case, the pure questions of law. ${ }^{76^{2}}$ In those comparatively rare cases, however, which turn upon a pure question of law, arbitration can prove both dilatory and expensive; for it merely involves one or two additional hearings as a preliminary to the progress through the courts. ${ }^{77}$ Nor should it be overlooked that court fees are nominal as compared with the substantial fees charged by a legal umpire and two experienced commercial men, in, say, a shipping arbitration lasting over several days. Furthermore, the advantages of the precedent set by a judgment should not be forgotten. ${ }^{78}$

It is sometimes argued ${ }^{79}$ that the impossibility of ousting the jurisdiction of the court on questions of law is a defect in the English system of arbitration, which ( $\mathrm{I}$ ) discourages foreign merchants from entering into contracts in a country where their commercial disputes may be dragged through the courts, and (2) is an obstacle to the establishment of a uniform international system of arbitration. The latter consideration is outside the scope of this article. Of the former it is perhaps not unfair to say that it is belied by the willingness of merchants all over the world, for a period of sixty years and more, to sign standard contract forms-often for the purpose of transactions which have no other connection with England-in which they agree to submit any dispute to "London arbitration." does the commercial world generally resent this ultimate sanction of the court; on the contrary, it is felt to be desirable that in the final analysis questions of law can be decided by reference to the judiciary. Indeed there are many who feel today that in a country which still prides itself on the rule of law, the ultimate control which the courts exercise over arbitration should be extended to other fields rather than retrenched.

\footnotetext{
7o See, for example, Mediterranean \& Eastern Export Co., Ltd. v. Fortress Fabrics (Manchester), Ltd., [1948] 2 All E.R. 186.

${ }_{\text {70a }}$ But see Aronson v. Mologa Holzindustrie A/C Leningrad, (1928) 138 L.T. 470, 473, per Atkin, L.J.

${ }^{77}$ See the comments of Singleton, L.J., in Sethia, Ltd. v. Partabmull Rameshwar, [1950] I All E.R. 5I, 58, and in Minister of Materials v. Skeel Bros. and Co., Ltd., [1952] I T.L.R. 499, 501.

${ }^{8}$ Thus, the Secretary of the Airbrokers Association writes, "It can be taken for granted that in a comparatively new and fast growing industry (i.e., Air Transport) it is advantagcous that the jurisdiction of the Courts cannot be wholly excluded."

${ }^{70}$ See, in particular, Sir Lynden Macassey, K.C., Anglo-French Legal Conference 1947; letter to The Times, August 27, 1947; The Journal of the Institute of Arbitrators (Incorporated) (December, I946), (March 1950).

${ }^{80}$ In some branches of commerce, certain individuals in London have come to be so frequently engaged as arbitrators as to have become in effect professional arbitrators, doing little else for their livelihood.
} 